\title{
Multiple Technologies Applied to Characterization of the Porosity and Permeability of the Biscayne Aquifer, Florida
}

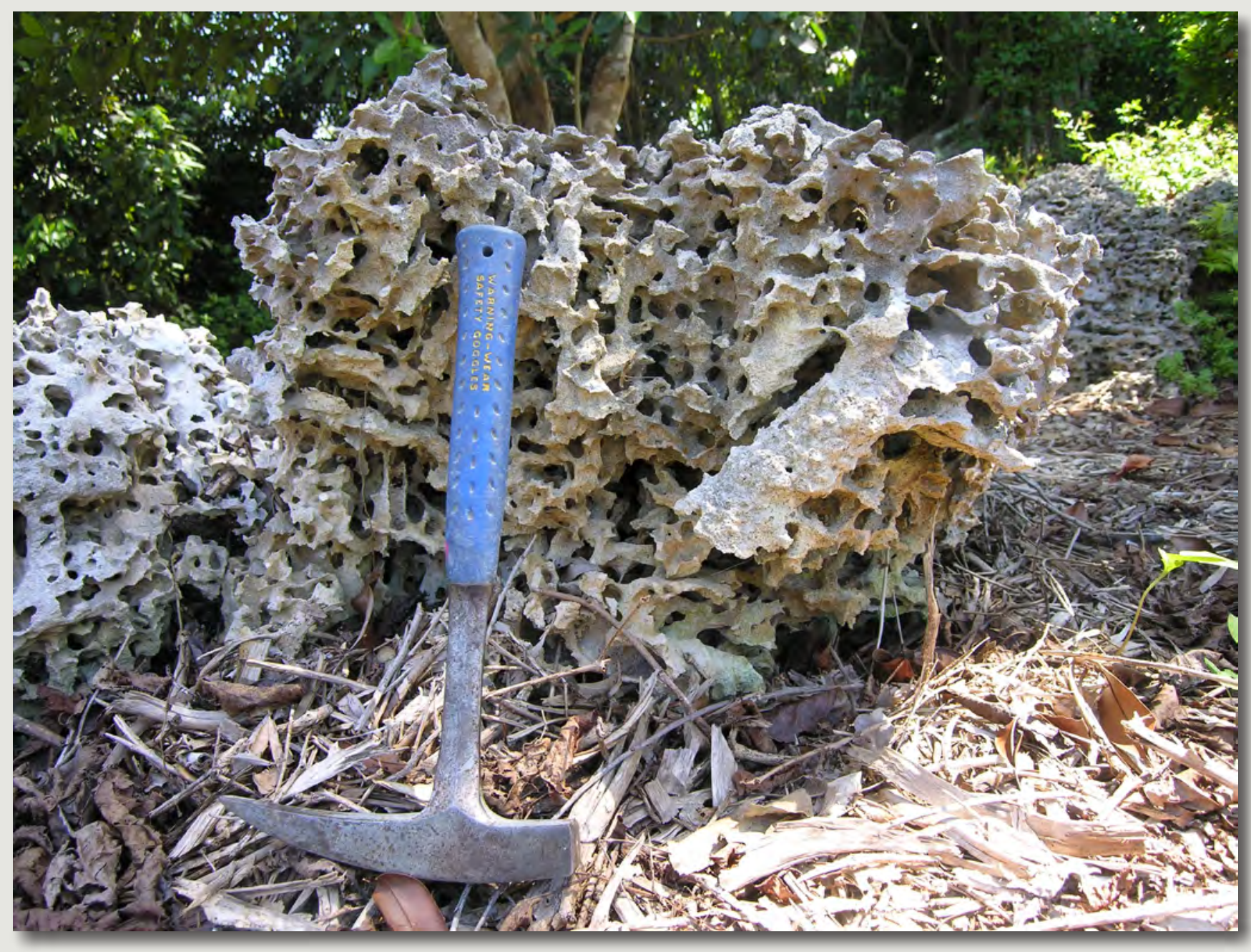

Irregular topography on karstic upper surface of the Miami Limestone in Miami-Dade County shows an example of highly macroporous oolitic limestone. The macroporosity is related to an Ophiomorpha-dominated ichnofabric. The sample shown in figure 5 was collected at this site. Photograph by Kevin Cunningham, USGS. Terms defined in the glossary are shown in boldface type where first used in the text.

R esearch is needed to determine how seepage-control actions planned by the Comprehensive Everglades Restoration R Plan (CERP) will affect recharge, groundwater flow, and discharge within the dual-porosity karstic Biscayne aquifer where it extends eastward from the Everglades to Biscayne Bay. A key issue is whether the plan can be accomplished without causing urban flooding in adjacent populated areas and diminishing coastal freshwater flow needed in the restoration of the ecologic systems. Predictive simulation of groundwater flow is a prudent approach to understanding hydrologic change and potential ecologic impacts. A fundamental problem to simulation of karst groundwater flow is how best to represent aquifer heterogeneity. Currently, U.S. Geological Survey (USGS) researchers and academic partners are applying multiple innovative technologies to characterize the spatial distribution of porosity and permeability within the Biscayne aquifer. 


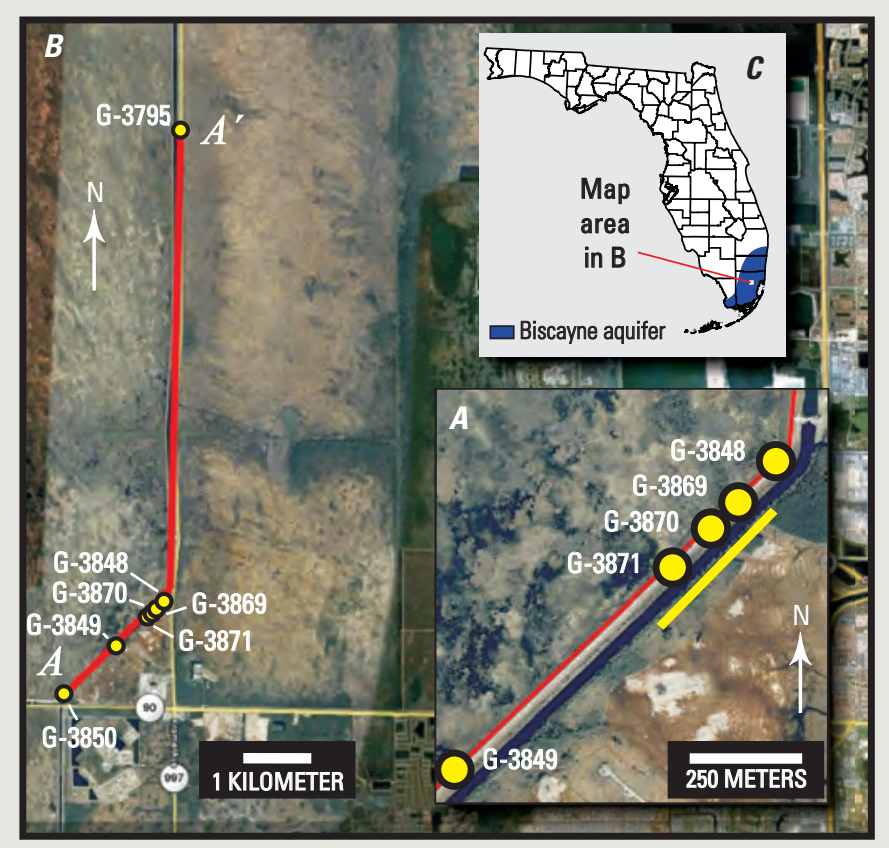

Figure 1. Generalized location of $(A)$ pilot seepage feature (yellow bar) to be constructed for the L-31N (L-30) Seepage Management Pilot Project, $(B)$ cross-section $A-A^{\prime}$ shown in figure 3 , and $(C)$ map area in $(B)$ and extent of Biscayne aquifer.

\section{Biscayne Aquifer Pore and Permeability Network}

The hydrologic properties of carbonate aquifers are highly variable, most notably in their heterogeneous permeability (Brahana and others, 1988). The Biscayne aquifer comprises karst carbonate rocks having a heterogeneous and anisotropic pore network with a range of measured permeability values that is at least 13 orders of magnitude (Cunningham and others, 2004, 2006a,b; 2009). The Biscayne aquifer is considered a dual-porosity system (Renken and others, 2008; Cunningham and others, 2009), because it consists of (1) matrix porosity (interparticle pores and separate vugs), which provides much of the groundwater storage; and (2) touching-vug macroporosity, which can create stratiform, areally extensive, groundwater flow pathways and less commonly observed bedding-plane and cavernous vugs, vertical solution pipes, and solution-enlarged fractures.

Groundwater flow in the Biscayne aquifer is particularly difficult to characterize because of a broad range in pore size and complicated pore connectivity. A diverse permeability network represents a significant challenge to the accurate simulation of dual-porosity karst groundwater flow. State-of-the-art technologies, including ichnologic, cyclostratigraphic, borehole geophysical, and computational methods, are being utilized by USGS scientists and their colleagues to accurately conceptualize and simulate groundwater flow through the Biscayne aquifer.

\section{Ichnology}

Ichnology is the study of trace fossils, which are structures that were produced in sedimentary rock or other substrate by the activity or growth of organisms (Bromley, 1996). Examples of trace fossils include footprints produced by dinosaurs and burrows made by worms.
Ichnology has recently emerged as an important applied science in the field of petroleum geology, because bioturbation (disturbances in sedimentary rocks generated by organisms) can play a significant role in the hydraulic properties of hydrocarbonbearing sedimentary units (Pemberton and Gingras, 2005). However, the use of ichnology in hydrology has been rare. Nevertheless, the USGS has recently been successful in applying ichnology to enhance carbonate aquifer characterization and map groundwater flow zones when it is integrated with other data types and characterization methodologies (Cunningham and others, 2006a,b; 2009). In some of the carbonate rocks of the Biscayne aquifer, fossilized burrows have a dominant presence where concentrated groundwater flow occurs within extremely permeable, vuggy passageways of the aquifer. Most of these burrows were likely created by callianassid shrimp (Shinn, 1968; Curran and Martin, 2003) during and shortly after deposition of carbonate sediments in a shallow, tropical marine environment. The fossil burrows that have a pelletal lining are named Ophiomorpha.

The USGS is applying the science of ichnology to hydrologic questions related to the CERP L-31N (L-30) Seepage Management Pilot Project (fig. 1) and to other Biscayne aquifer studies. The CERP project, designed to resolve critical uncertainties associated with seasonally managing seepage flows, is located within one of the most transmissive parts of the Biscayne aquifer (U.S. Army Corps of Engineers, 2010). Borehole geophysical data acquired by the USGS demonstrate that the very high transmissivities are related to bedded macroporous zones of intensely burrowed limestone (figs. 1-3). Delineating the continuity and lateral extent of these borrowed flow units is important to the conceptualization of groundwater flow at the site, and could be very useful in design and interpretation of aquifer performance tests and tracer tests (Renken and others, 2005, 2008; Cunningham and others, 2006a).

\section{Cyclostratigraphy}

Sequence stratigraphy is a newer conceptual advance in the expansive field of sedimentary geology (Miall, 1995), and has transformed the methodology of stratigraphic analysis. High-frequency cycles (HFCs) are the fundamental building blocks of sequence stratigraphy and often occur as discernable, repetitive vertical changes in lithostratigraphy. The delineation and use of HFCs for correlation is cyclostratigraphy. A cyclostratigraphy comprised of four types of ideal cycles has been described for the Miami Limestone and Fort Thompson Formation, which compose most of the Biscayne aquifer (Cunningham and others, 2009). In the context of these ideal cycles, stratiform zones of densely packed Ophiomorpha have a predictable pattern in their vertical arrangement.

Concentration of Ophiomorpha in macroporous, extremely permeable zones in lower to middle parts of HFCs is common in upward-shallowing subtidal and upward-shallowing paralic cycles (figs. 2 and 3) - the dominant ideal cycle types of the Fort Thompson Formation (Cunningham and others, 2009). Specific physical characteristics of the tops and bottoms of the cycles, and the vertical and lateral arrangement of their lithostratigraphy and paleoenvironments provide a means for correlation and mapping of the macroporous and highly permeabable parts of the cycles. Thus, cyclostratigraphy can provide a realistic framework for hydrogeologic conceptual models when it is used as input for groundwater-flow simulations. 


\section{Borehole Geophysics}

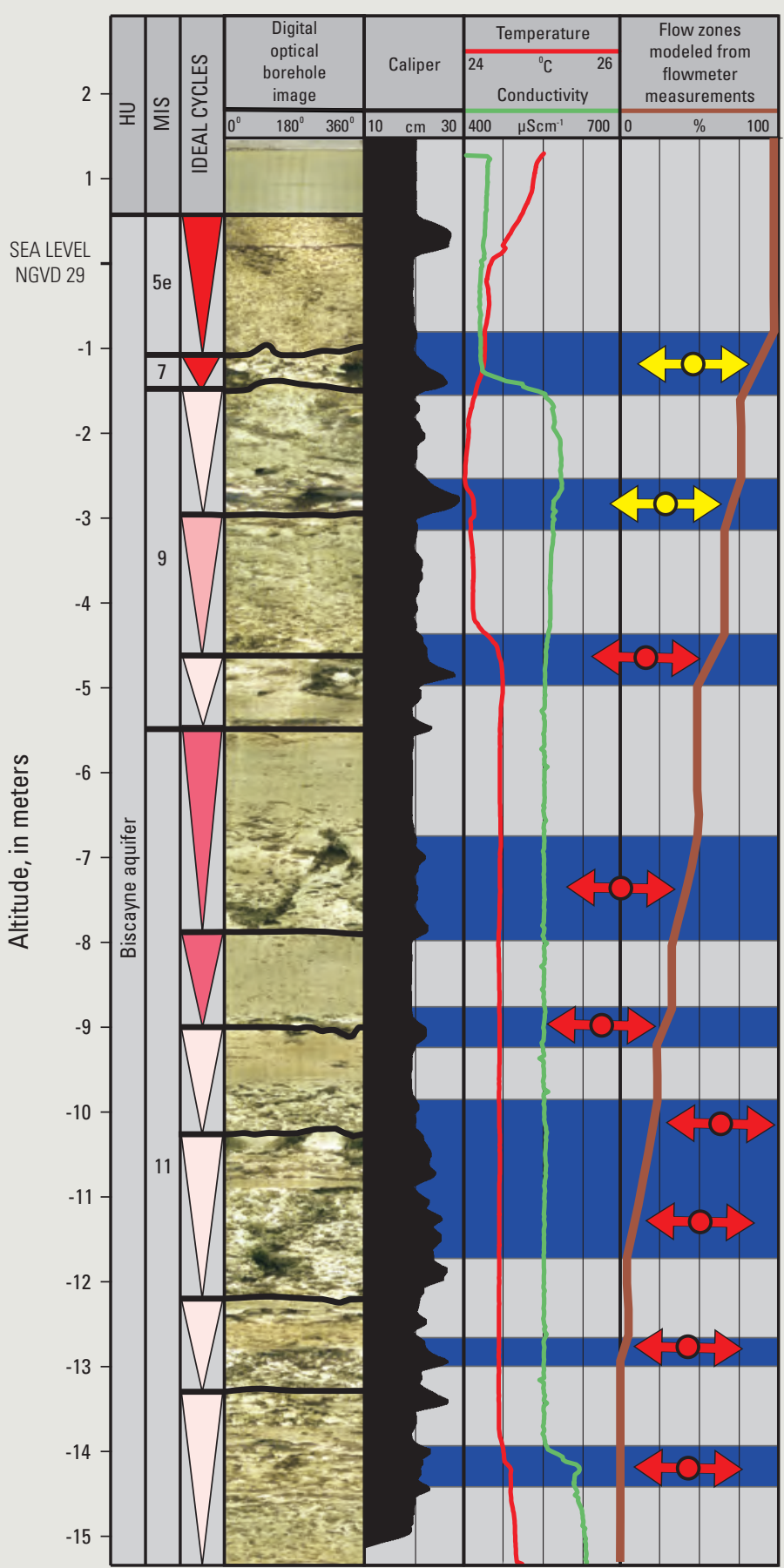

EXPLANATION

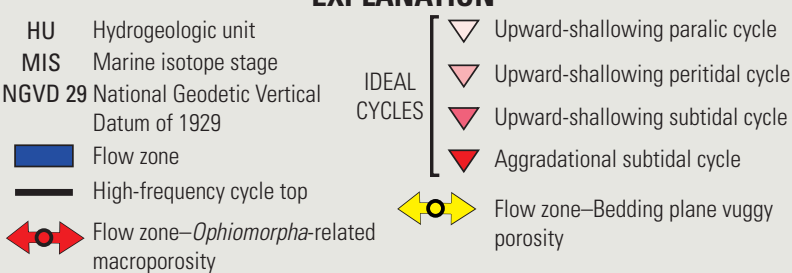

Figure 2. Interpreted flow zones from digital optical borehole images and flowmeter, temperature, and conductivity measurements acquired in corehole G-3871 at the L-31N (L-30) Seepage Management Pilot Project (figs. 1 and 3).
Rock-core recovery using traditional coring procedures generally is problematic in more delicate macroporous, vuggy, groundwater flow zones. For these reasons, the USGS uses groundwater wells as a subsurface laboratory. Innovative logging tools provide reliable data on the physical properties of the rocks, water quality, and fluid flow within the subsurface borehole environment (Wacker and Cunningham, 2008). The USGS digital optical borehole imaging tool is markedly useful, because it offers a high-resolution image of the borehole wall and cross-sectional photo map of the macropore network (figs. 2 and 3). Cunningham and others, $(2006 \mathrm{a}, \mathrm{b})$ have shown that the combination of digital image logs, caliper logs, water-quality logs (conductivity and temperature), and flowmeter measurements are effective in evaluating concentrated groundwater flow (figs. 2 and 3).

Borehole flowmeters measure vertical flow within a single well, and the data used to identify areas of inflow into or outflow from the borehole. Differences in hydraulic head produce vertical flow within the borehole, which is measured by the flowmeter. Interpreted results from flowmeter data combined with other log data from the coreholes shown in figure 3 indicate that vertically stacked, multistoried layers of macroporous Ophiomorphadominated zones form an extremely transmissive aquifer (especially in the lower part of the HFCs) over a lateral distance of at least 8.4 kilometers (fig. 3 ). The broad continuity of the permeable zones depicted in figure 3 corroborates the conclusions, reported by Renken and others (2005), Cunningham and others (2006a,b; 2009), Renken and others (2008), and Shapiro and others (2008), that highly permeable zones of touching-vug macroporosity related to burrowing can form principal passageways for concentrated groundwater flow in the Biscayne aquifer.

\section{Computational Methods}

The permeability of touching-vug macroporosity networks in carbonate rocks is exceedingly difficult to measure with traditional permeameter methodology. This is due to flow-rate limitations of the apparatus and issues related to imposing and maintaining the extremely small gradients needed to sustain Darcian flow regimes during operation of the instrumentation. Unfortunately, the upper range of accurate measurements of whole-core permeability using the permeameter method does not exceed about 10 to 30 Darcies, or about 0.0001 to 0.0003 meter per second (Cunningham and others, 2009). The inability to obtain large permeability values from permeameter measurements of macroporous limestone samples impedes core-scale hydrologic characterization. Frequently used for computational modeling of small-scale fluid flow, Lattice Boltzmann methods (LBM; Sukop and Thorne, 2006) are ideally suited for accurate core-scale calculation of the exceptionally high permeabilities of the Biscayne aquifer, which can be much larger values than a permeameter can measure. Figure 4 shows that permeability of Biscayne aquifer Ophiomorpha-related macropore networks can be 3 to 6 orders of magnitude larger than permeameter-based measurements. LBM simulations closely conform to analytical solutions for pipe flow, providing the impetus and justification for its application to carbonate macropore systems. 


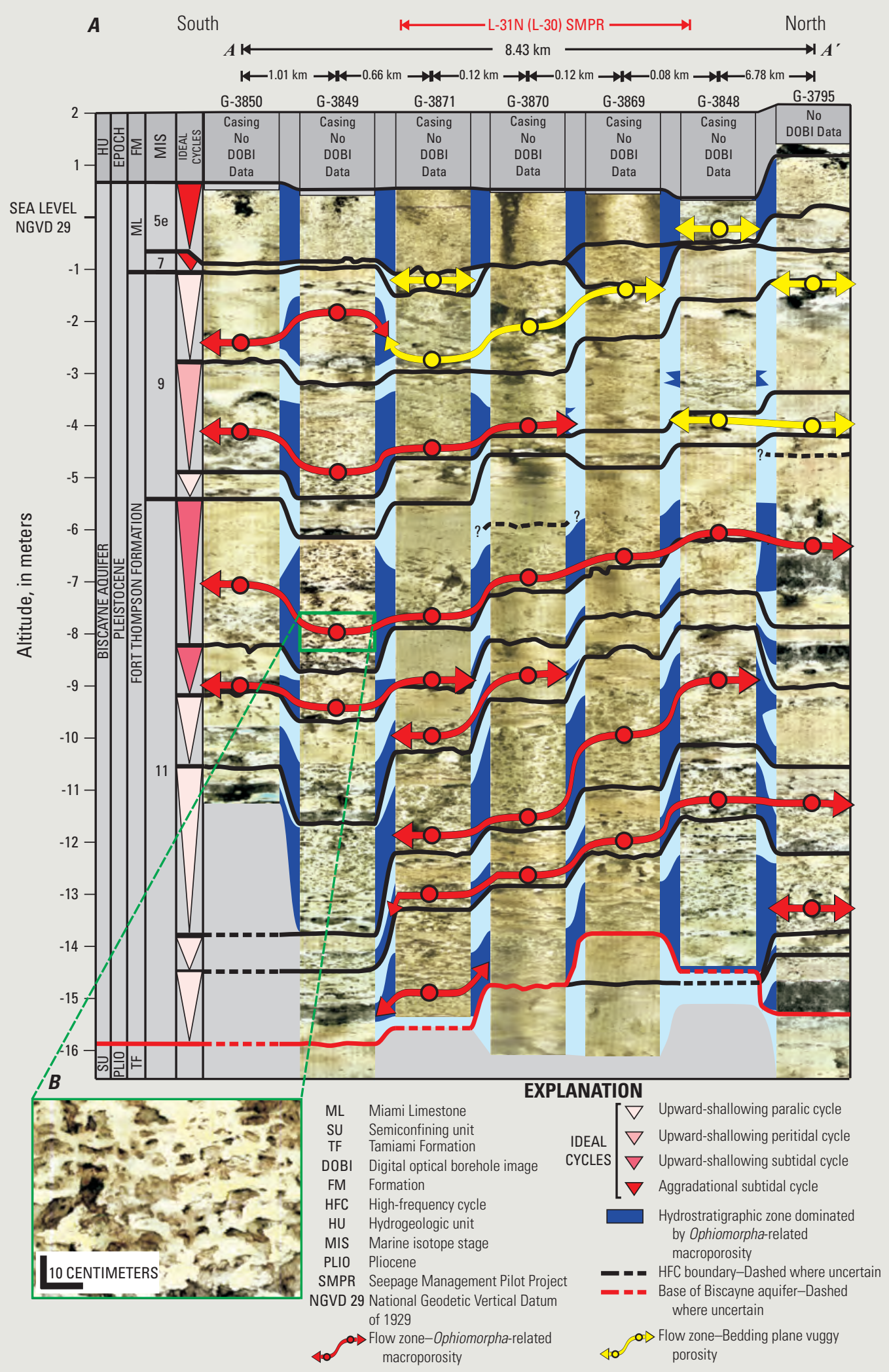

Figure 3. Hydrogeologic cross-section in the area of the L-31N (L-30) Seepage Management Pilot Project (fig. 1). (A) Hydrologic units, geologic units, marine isotope stages, high-frequency cycles, ideal cycles, and correlation of zones of matrix porosity and zones of macroporosity related to either bedding-plane vugs or Ophiomorpha-dominated ichnofabric, and where preferential flow within the vuggy zones is confirmed by flowmeter measurements (red and yellow arrows).

(B) Touching-vug macropority related to an Ophiomorpha-dominated ichnofabric. 


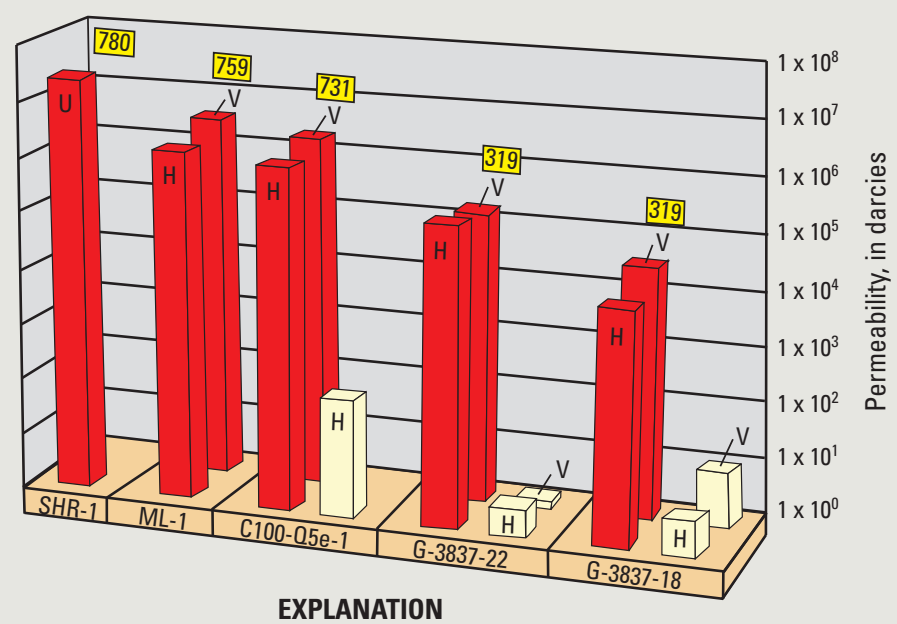

of carbonate macroporosity. A thresholding process is used to partition the digital imagery into macropores and nonpermeable rock matrix (fig. $7 B$ ). Three-dimensional coordinate information is extracted that defines the presence or absence of rock matrix at individual image pixels of the borehole wall. Variograms for the 3-D data are computed, and a 3-D simulation is created of a volume comprised of only two components: macroporosity and rock matrix (fig. 7C).

Experimentation with this methodology (Sukop and others, 2008) may extend the use of variograms to predict flow-zone continuity between wells. A major goal of this work is to use LBM to simulate field-scale groundwater flow, providing an alternative to continuum models based on equivalent porous media flow.

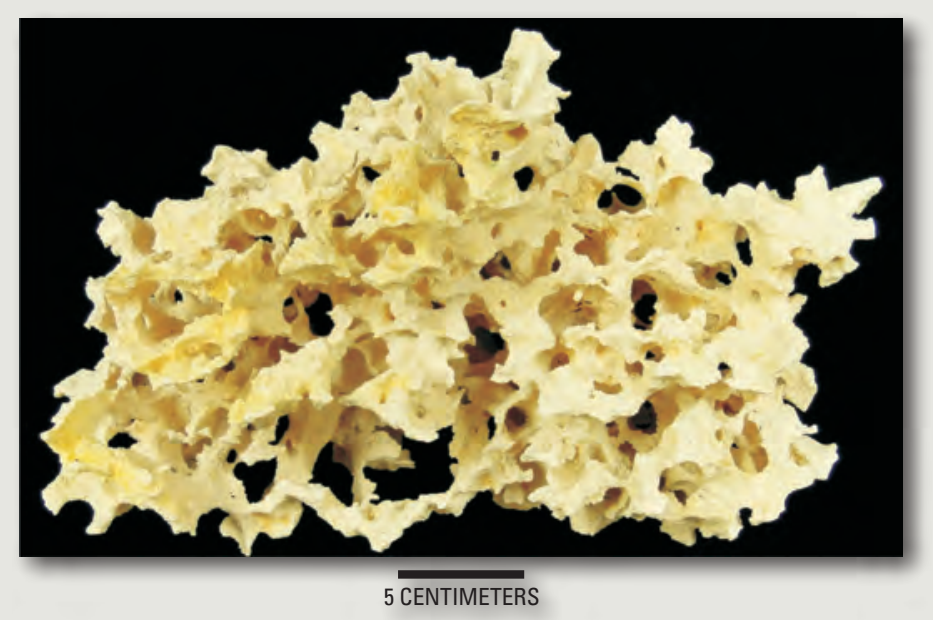

Figure 5. Sample of highly porous oolitic Miami Limestone that displays visible limestone macroporosity related to an Ophiomorpha-dominated ichnofabric. Photograph by Richard Wescott, USGS. Ophiomorpha-related macroporosity (fig. 4). LBM measurements in figure 4 should approximate the range in permeabilities of the flow zones identified in figure 3 using digital optical images and flowmeter measurements. Research is in progress to investigate the validity of the conceptual assumption that core-scale LBM calculated intrinsic permeability values are representative of field-scale pore networks. LBM also is being used to determine whether ambient flow is laminar or turbulent. Non-Darcian effects are of considerable interest if they occur under field-scale conditions (Shoemaker and others, 2008). Sukop and others (2008) concluded that non-Darcian behavior due to inertial flow under field-scale gradients could effectively reduce the apparent hydraulic conductivity within well-connected macroporosity by nearly 50 percent. Future LBM groundwater flow simulations will examine the impact of non-Darcian flow on field-scale hydraulic conductivity.

Predicting where concentrated groundwater flow occurs is important, especially in areas that have not yet been investigated by coring and logging methodologies. Therefore, experimentation with spatial prediction is being conducted through the use of variograms, a quantitative descriptive statistical tool that can be used graphically to characterize spatial continuity. Digital images of borehole walls (fig. $7 A$ ) are used to create approximately 0.2 -meter-wide 3 -D renderings

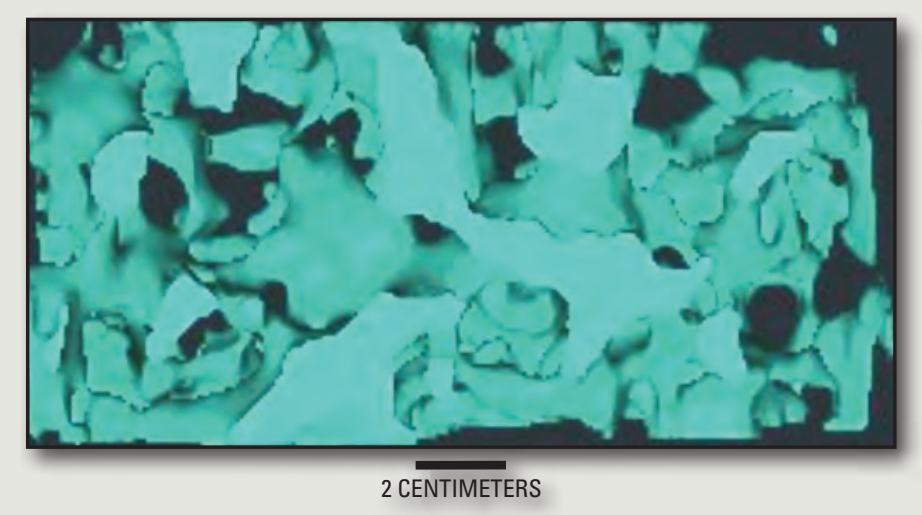

Figure 6. Computer rendering created from sample SHR-1 (fig. 5) collected at an outcrop of the Miami Limestone (cover photo). The limestone macroporosity is related to a Ophiomorphadominated ichnofabric. Light-blue areas represent rock matrix and darker areas macroporosity. LBM-calculated permeability of the macroporosity (78 percent) is $2.7 \times 10^{7}$ Darcies (fig. 4). CT-scan acquired at the High-Resolution X-Ray CT Facility at the University of Texas. 

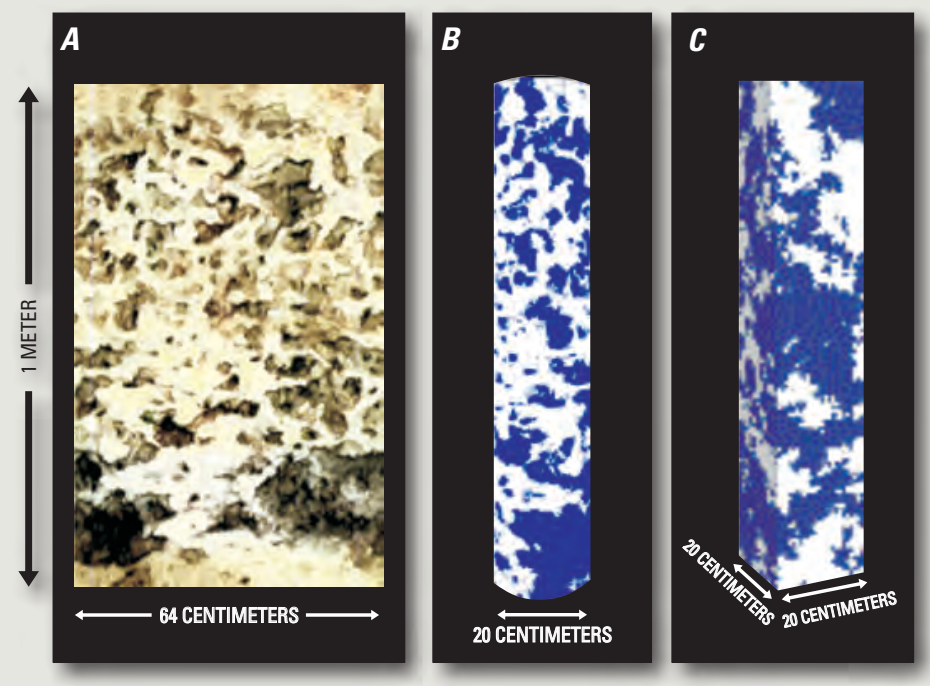

\section{Conclusions}

A major challenge to evaluating groundwater flow in the Biscayne aquifer is characterizing and simulating the complex geometry of its porosity and permeability networks. The USGS has expanded its integrated use of ichnology, cyclostratigraphy, borehole geophysics, and computational methods to characterize the Biscayne aquifer between the Florida Everglades and Biscayne Bay. The motivation of this research is to better understand the hydraulic properties of the Biscayne aquifer and to upscale core- and borehole-scale hydrogeologic characterizations to a field-scale conceptualization. An example of application of this research strategy is at the L-31N (L-30) Seepage Management Pilot Project site, underlain by one of the most transmissive parts of the Biscayne aquifer. The exceptionally large transmissivity in this area is attributed to a limestone sequence of multistoried Ophiomorpha-dominated groundwater flow zones comprised of vuggy macroporosity that are compartmentalized within high-frequency cycles. This conceptualization of Biscayne aquifer macroporosity is a shift from earlier conceptualizations of the aquifer as an equivalent porous medium. Maps showing the spatial continuity of highly permeable flow zones are being developed to improve modeled conceptualization of groundwater flow. Ultimately, this information will be used to aid sustainable use, protection,

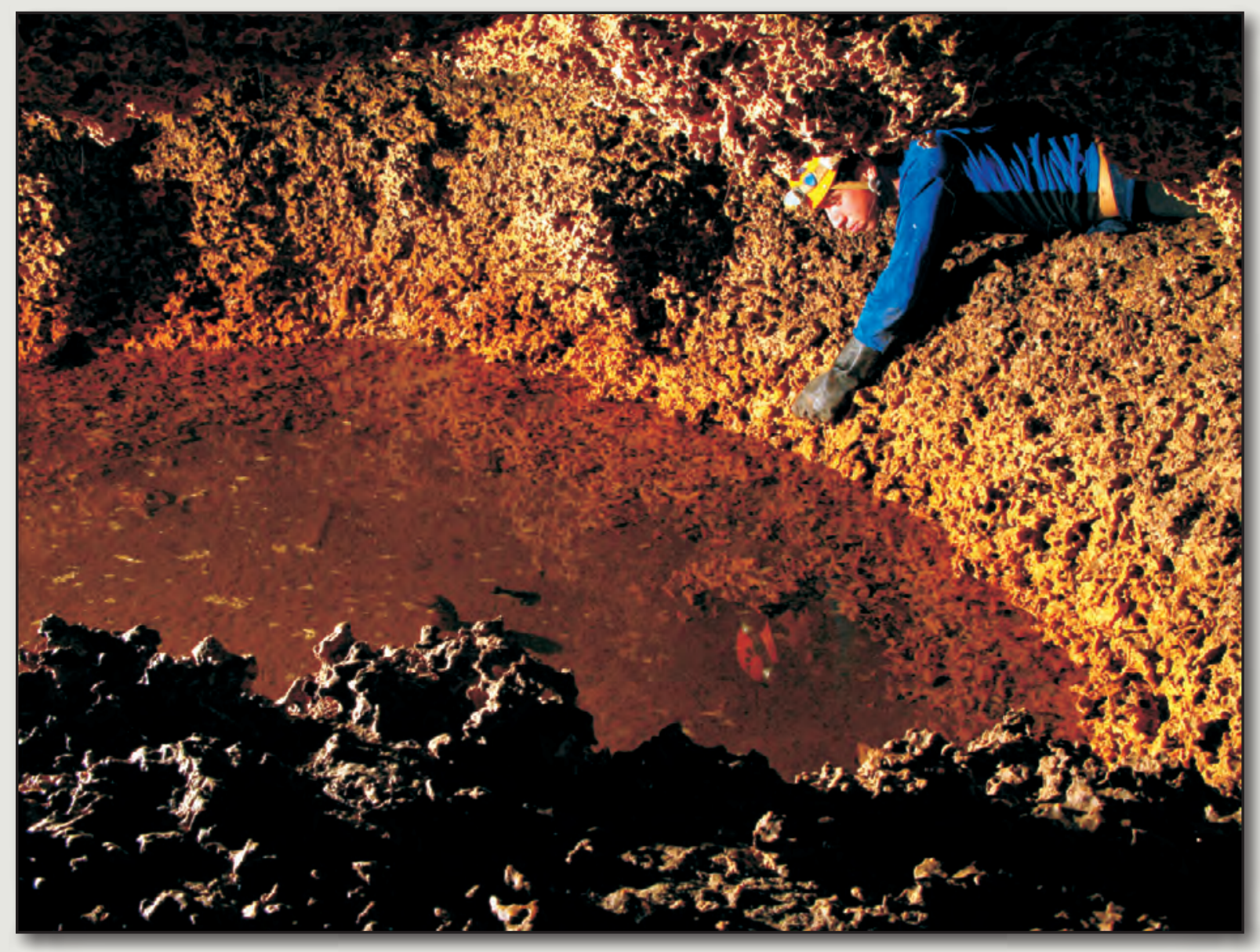

Large cave that formed in the Miami Limestone where it is dominated by a stratiform Ophiomorpha ichnofabric (fig. 4; from Cunningham and others, 2008). Photograph by Alan Cressler, USGS. 


\section{Glossary}

Cyclostratigraphy — The study of stratified rock in relation to cyclic formation and destruction.

Ichnofabric-All aspects of the texture and internal structure of a substrate that result from bioturbation and bioerosion on all scales (Ekdale and Bromley, 1983; Bromley and Ekdale, 1986).

Ideal cycle-A sedimentary cycle that includes both stages of a rise and fall of relative sea level, in which the interplay of relative sealevel change and sediment supply or production results in a predictable arrangement of vertical lithofacies (see Helland-Hansen, 2009).

High-frequency cycle-The smallest set of sediment deposited during a single relative rise and fall in sea level.

Vug - A "pore space that is within grains or crystals or that is substantially larger than grains or crystals," but does not include interparticle pore space (Lucia, 1995). Vugs are commonly present as leached fossils or other grains, fractures, and large, irregular cavities.

and restoration of the Everglades and other ecosystems within the region. Lattice Boltzman methods and new geostatistical approaches are offering practical approaches to the delineation of karst carbonate heterogeneity and the understanding of concentrated groundwater flow within the Biscayne aquifer.

\section{By Kevin J. Cunningham and Michael C. Sukop}

\section{References Cited}

Brahana, J.V., Thrailkill, John, Freeman, Tom, and Ward, W.C., 1988, Carbonate rocks, in Back, W. Rosenshein, J.S., and Seaber, P.R., eds., Hydrogeology: Boulder, CO, Geological Society of America, The Geology of North America, v. O-2, p. 333-352.

Bromley, R.G., 1996, Trace fossils: Biology, taphonomy and applications (2d ed.): London, Chapman \& Hall, 361 p.

Bromley, R.G., and Ekdale, A.A., 1986, Composite ichnofabrics and tiering of burrows: Geological Magazine, v. 123, p. 59-65.

Cunningham, K.J., Carlson, J.L., Wingard, G.L., Robinson, Edward, and Wacker, M.A., 2004, Characterization of aquifer heterogeneity using cyclostratigraphy and geophysical methods in the upper part of the karstic Biscayne aquifer, southeastern Florida: U.S. Geological Survey Water-Resources Investigation Report 03-4208, 46 p.

Cunningham, K.J., Renken, R.A., Wacker, M.A., Zygnerski, M.R., Robinson, Edward, Shapiro, A.M., and Wingard, G.L., 2006a, Application of carbonate cyclostratigraphy and borehole geophysics to delineate porosity and preferential flow in the karst limestone of the Biscayne aquifer, SE Florida, in Harmon, R.S., and Wicks, C., eds., Perspectives on karst geomorphology, hydrology, and geochemistry - A tribute volume to Derek C. Ford and William B. White: Geological Society of America Special Paper 404, p. 191-208.
Cunningham, K.J., Sukop, M.C., Huang, H., Alvarez, P.F., Curran, H.A., Renken, R.A., and Dixon, J.F., 2009, Prominence of ichnologically influenced macroporosity in the karst Biscayne aquifer: stratiform "super-K" zones: Geological Society of America Bulletin, v. 121, no. 1/2, p. 164-180.

Cunningham, K.J., Sukop, M.C., Huang, H., Alvarez, P.F., Curran, H.A., Wacker, M.A., Florea, L.J., Renken, R.A., and Dixon, J.F., 2008, Biogenic macroporosity and its lattice Boltzmann method permeability in the karst Biscayne aquifer, in Sasowsky, I.D., Feazel, C.T., Mylroie, J.E., Palmer, A.N., and Palmer, M.V., eds., Karst from Recent to Reservoirs: Special Publication 14, Karst Waters Institute Proceedings, Leesburg, VA, p. 30-35.

Cunningham, K.J., Wacker, M.A., Robinson, Edward, Dixon, J.F., and Wingard, G.L., 2006b, A cyclostratigraphic and borehole geophysical approach to development of a threedimensional conceptual hydrogeologic model of the karstic Biscayne aquifer, southeastern Florida: U.S. Geological Survey Scientific Investigations Report 2005-5235, 69 p.

Curran, H.A., and Martin, A.J., 2003, Complex decapod burrows and ecological relationships in modern and Pleistocene intertidal carbonate environments, San Salvador Island, Bahamas: Palaeogeography, Palaeoclimatology, Palaeoecology, v. 192, p. 229-245.

Ekdale, A.A., and Bromley, R.G., 1983, Trace fossils and ichnofabric in the Kjølby Gaard Marl, Upper Cretaceous, Denmark: Bulletin of the Geological Society of Denmark, v. 31, p. 107-119.

Helland-Hansen, W., 2009, Towards the standardization of sequence stratigraphy-Discussion: Earth-Science Reviews, v. 94 , p. 95-97.

Lucia, F.J., 1995, Rock-fabric/petrophysical classification of carbonate pore space for reservoir characterization: American Association of Petroleum Geologists, v. 79, p. 1275-1300. 
Miall, A.D., 1995, Whither stratigraphy?: Sedimentary Geology, v. 100 , p. $5-20$

Pemberton, S.G., and Gingras, M.K., 2005, Classification and characterizations of biogenically enhanced permeability: American Association of Petroleum Geologists Bulletin, v. 89, no. 11, p. 1493-1517.

Renken, R.A., Cunningham, K.J., Shapiro, A.M., Harvey, R.W., Zygnerski, M.R., Metge, D.W., and Wacker, M.A., 2008, Pathogen and chemical transport in the karst limestone of the Biscayne aquifer: 1. Revised conceptualization of groundwater flow, Water Resources Research 44, W08429, doi:10.1029/2007WR006058.

Renken, R.A., Shapiro, A.M., Cunningham, K.J., Harvey, R.W., Metge, D.W., Zygnerski, M.R., Wacker, M.A., Osborn, C.L., and Ryan, J.N., 2005, Assessing the vulnerability of a municipal well field to contamination in a karst aquifer: Environmental Engineering Geoscience Journal, v. 11, no. 4, p. 341-354.

Shapiro, A.M., Renken, R.A., Harvey, R.W., Zygnerski, M.R., and Metge, D.W., 2008, Pathogen and chemical transport in the karst limestone of the Biscayne aquifer: 2. Chemical retention from diffusion and slow advection: Water Resources Research, v. 44, W08430, doi:10.1029/2007WR006059. Shinn, E.A., 1968, Burrowing in recent lime sediments of Florida and the Bahamas: Journal of Paleontology, v. 42, p. 879-894.
Shinn, E.A., 1968, Burrowing in recent lime sediments of Florida and the Bahamas: Journal of Paleontology, v. 42, p. 879-884.

Shoemaker, W.B., Cunningham, K.J., Kuniansky, E.L., and Dixon, J., 2008, Effects of turbulence on hydraulic heads and parameter sensitivities in preferential groundwater flow layers: Water Resources Research, v. 44, W03501, doi:10.1029/2007WR006601.

Sukop, M.C., Anwar, S., Lee, J.S., Cunningham, K.J., and Langevin, C.D., 2008, Modeling ground-water flow and solute transport in karst with Lattice Boltzmann methods, in Kuniansky, E.L., ed., Proceedings of the U.S. Geological Survey Karst Interest Group Workshop, May 27-29, 2008, Bowling Green, Kentucky: U.S. Geological Survey Scientific Investigations Report 2008-5023, p. 77-86.

Sukop, M.C., and Thorne, D.T., Jr., 2006, Lattice Boltzmann modeling: An introduction for geoscientists and engineers: New York, Springer, 172 p.

Wacker, M.A., and Cunningham, K.J., 2008, Borehole geophysical logging program: Incorporating new and existing techniques in hydrologic studies: U.S. Geological Survey Fact Sheet 2008-3098, 4 p.

U.S. Army Corps of Engineers, 2010, CERP Project-L-31N (L-30) Seepage Management Pilot: Accessed July 23, 2010, at http://www.evergladesplan.org/pm/projects/proj_36_l31n_ seepage.aspx.
For further information on carbonate aquifer characterization, contact:

Kevin J. Cunningham

U.S. Geological Survey

3110 SW 9th Avenue

Fort Lauderdale, FL 33315

E-mail: kcunning@usgs.gov
For further information on Lattice Boltzmann

methods and geostatistics, contact:

Michael C. Sukop

Department of Earth \& Environment

Florida International University

Miami, FL 33199

E-mail: sukopm@fiu.edu
For more information on the USGS - the Federal source for science about the Earth, its natural and living resources, natural hazards, and the environment: World Wide Web: http://www.usgs.gov Telephone 1-888-ASK-USGS
Any use of trade, product or firm names is for descriptive purposes only and does not imply endorsement by the U.S. Government
ISBN $978-1-4113-3028-3$

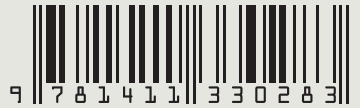

